Ляшук, Наталія. «Моделювання національного стереотипу в романі Ліни Костенко „Записки українського самашедшого"». Лінгвостилістичні студії, вип. 13, 2020, с. 103-11.

Lyashuk, Natalia. "Nation Stereotype Modeling in the Novel "Notes of a Ukrainian Madman" by Lina Kostenko". Linguostylistic Studies, iss. 13, 2020, pp. 103-11.

УДК 811.161.2.09 Костенко

https://doi.org/10.29038/2413-0923-2020-13-103-111

\title{
МОДЕЛЮВАННЯ НАЦІОНАЛЬНОГО СТЕРЕОТИПУ В РОМАНІ ЛІНИ КОСТЕНКО «ЗАПИСКИ УКРАЇНСЬКОГО САМАШЕДШОГО»
}

\author{
Наталія Ляшук \\ Луцький інститут розвитку людини вищого навчального закладу \\ «Відкритий міжнародний університет розвитку людини „Україна”», \\ Луцьк, Україна
}

У статті розглянуто особливості функціонування національного стереотипу в романі Ліни Костенко «Записки українського самашедшого»; здійснено аналіз основних концептуальних понять, що моделюють авторський стереотип української нації; акцентовано увагу на різноманітті мовностилістичних засобів актуалізації характерних ознак українців. Встановлено комплекс оцінних номінацій, що конструюють модель національного стереотипу. Визначено чинники, що могли вплинути на індивідуальне сприйняття і відтворення автостереотипу в художньому тексті.

Ключові слова: мовностилістичні засоби, художній текст, автокомунікація, номінативне поле.

\section{NATION STEREOTYPE MODELING IN THE NOVEL “NOTES OF A UKRAINIAN MADMAN” BY LINA KOSTENKO}

\author{
Natalia Lyashuk \\ Higher educational institution "Open International University of Human Development \\ "Ukraine”"' (Lutsk Institute of Human Development), Lutsk, Ukraine
}

The article considers the peculiarities of the nation stereotype functioning in the novel Notes of a Ukrainian Madman by Lina Kostenko. In the focus of the analysis are the basic concepts (the nation, the people, Ukrainians, the state, a society), by means of which the author's stereotype of the Ukrainian nation is revealed. A set of evaluative nominations that construct a model of the nation stereotype has been established. The greatest number of epithets refers to the lexeme nation. They create a nominative field of the author's stereotype and express mostly negative connotations.

The study has revealed that the expression of the author's model of the stereotype is the image of the protagonist as a representative of the society of the Ukrainians, living in the XX-XXI centuries, whose communicative behavior demonstrates an evaluative attitude to his people. Evaluative nominations that construct a model of national stereotype in the text of the novel are mostly endowed with negative connotations and high expressiveness.

The usage features of various linguistic and stylistic means, metaphorical techniques, as well as occasionalisms, loanwords, ethnonymes in the author's representation of the

(C) Ляшук Н., Волинський національний університет імені Лесі Українки, 2020.

Це стаття відкритого доступу на умовах CC BY-NC 4.0 
Ukrainian nation are analyzed. Verbalization of the image of Ukraine is carried out by means of syntactic constructions of monologue, dialogue, and quotation.

The factors that could influence the individual perception and reproduction of the nation stereotype in the literary text are identified. The author's stereotype in the analyzed work appears not idealized, but, due to the individual experience of the writer, social and political factors, critically considered.

Prospects for further research on national stereotypes in linguistics concern the development of the criteria for selecting factual material, texts of various functional styles and genres, as well as the comparative study of the specifics of modeling stereotypes, their verbalization and dynamics in the works of different writers.

Key words: national stereotype, linguistic stylistic means, literary text, autocommunication, nominative field.

Вступ. Сучасна лінгвістика часто застосовує поняття стереотип для дослідження культурологічної парадигми національних мов, вивчення ментальних особливостей носіїв певної мови та культури. Зокрема, дослідники активно вивчають специфіку функціонування стереотипів, їх вербальне вираження у фольклорній традиції (Белова; Годзь; Кісь; Ляшук), на основі публіцистики (Фалафівка), у художній літературі та епістолярії (Богдан; Серебрянська; Трифонов, і Стратілат). Особлива увага приділена когнітивній та конативній природі стереотипу, його значенню в міжкультурній комунікації (Bartmiński; Бацевич; Маслова; Попович).

Однак, на сьогоднішній день недостатньо вивченою залишається проблема функціонування етнічних стереотипів у текстах художньої літератури, що постають виразниками національної ідентичності певного народу через призму авторського усвідомлення дійсності. Як слушно зауважує С. Богдан: «Очевидним $\epsilon$ і те, що стереотипи, створені етносом щодо себе та інших народів, формуються на основі колективного досвіду. Однак індивідуальні стереотипи не завжди збігаються з колективними, оскільки значною мірою відтворюють індивідуальні (почасти спорадичні, а не регулярні) враження від спілкування і взаємин із представниками власного та чужих етносів» («Україна» 19). Саме аналіз індивідуальних стереотипів та мовних засобів їхнього вираження у художніх творах певної епохи дасть можливість дослідити узгодженість, традиційність, стабільність чи динаміку стереотипних образів.

Важливим теоретичним підгрунтям для нашого дослідження $\epsilon$ висновок науковців про те, що «стереотип входить до структури ментально-лінгвального комплексу і репрезентує національні уявлення комунікантів; він не може функціонувати як одиничний феномен, оскільки стереотипи поліфонічні й діють як збірний образ. Стереотип виступає як універсальна поведінкова модель з детермінованим вибором тактики. На основі положення, що за мовними одиницями знаходяться стереотипи та асоціації, можна зрозуміти дію певних культурно-зумовлених уявлень» (Годзь 11). 
Мета дослідження - з'ясувати структуру автостереотипу, лінгвостилістичні засоби моделювання національного стереотипу, встановити систему номінацій, що формують характеристику української нації в романі Ліни Костенко «Записки українського самашедшого».

Матеріал і методи дослідження. Матеріалом наукової розвідки слугував роман Ліни Костенко «Записки українського самашедшого».

У дослідженні застосовано описовий метод для систематизації фактичного матеріалу; метод суцільної вибірки - для встановлення системи мовних одиниць, за допомогою яких авторка вербалізує національний стереотип. Метод контекстного аналізу допоміг вивчити семантико-синтаксичну структуру концептуальних лексем. Застосовано також прийоми лінгвостилістичного аналізу мовного матеріалу, його систематизації та інтерпретації.

Результати дослідження та дискусія. Національні стереотипи входять до розгалуженої структури етнічних стереотипів. За визначенням Ф. Бацевича, «національний стереотип - образ, який, позначаючи етнічну, або національну групу, передбачає наявність певної риси у всіх її представників» (260).

Аналіз художніх текстів уможливлює виокремлення мовних образів, комунікативних ситуацій, що моделюють національні стереотипи, сформовані індивідуально окремими письменниками. У творчості Ліни Костенко широко представлена характеристика української ментальності, яка реалізована гетеростереотипними (сприйняття українців світом) i автостереотипними (визначальні риси української нації) образами. Роман «Записки українського самашедшого» актуалізує насамперед національний автостереотип, вербалізує портрет української нації. Через призму свідомості українського інтелігента, головного героя роману, авторка репрезентує характерні риси українців, акцентуючи, щоправда, здебільшого увагу на недоліках і негативах.

У романі «Записки українського самашедшого» астостереотип складно структурований нелінійним взаємозв'язком концептуальних образів твору: Україна, нація, украӥнці, народ, суспільство. Відтворення автостереотипу здебільшого змодельовано за допомогою внутрішніх монологів головного героя, рідше - через побудову діалогу. Образ України репрезентовано через кореляцію понять держава - народ - украӥнці: «Украӥна - це резервація для українців. Жоден украӥнець не почувається своїм у своїй державі. Він тут чужий самим фактом вживання своєї мови» (Костенко 23).

Характеризуючи Україну як державу, авторка часто застосовує персоніфікацію і метонімію, які виокремлю певні ознаки українського суспільства: «Слухняна Україна, самороззброюється (Костенко 138); «<...> коли Україна поневолена, змучена, але бореться, то вона є. А коли вона ось така ніби вільна, ніби незалежна, а насправді невизначена, хистка, компромісна, то вона вже не спроможна бути» (Костенко 296). Для 
підсилення емоційності в зображенні стереотипу Україна влучно введено міфологічні образи в структуру порівняння: «Виїли Україну зсередини, як лисиця бік у спартанця, ще й дивуються - чого ж вона така скособочена? Чого кульгає в Європу, тримаючись за скривавлений бік?» (Костенко 23); «Украӥна пручається, як Лаокоон, обплутаний зміями. Вона німо кричить, але світ не чує. Або не хоче почути» (Костенко 197).

Домінувальним поняттям, за допомогою якого в тексті роману вербалізовано характерні риси українського народу, постає нація. Спостережено ряд контекстуальних синонімів: нація, народ, етнос, українці, що наділені виразними характеристиками: "А інші вправляються в протилежному. Нації ще нема, $\epsilon$ недолугий етнос» (Костенко 26); «Важко належати до такого народу. Націю запрограмували на безвихідь. А вона добра, вона терпляча. Вона, як я - Терези і Кінь» (Костенко 27); “Хто сказав, що українці селянська нація? Натепер ми вже нація модернова, нація на атомному підігріві» (Костенко 121).

Із лексемою нація зафіксовано найбільше епітетів, що становлять номінативне поле автостереотипу та виражають здебільшого негативну конотацію стереотипних ознак: аморфна, розпливчаста, анахронічна, терпляча, селянська, недорікувата, косноязика, не пасіонарна. Менш частотно використано характеристики з позитивною конотацією: добра, модернова, красива, шляхетна. Із негативною чи нейтральною конотацією також схарактеризовані й інші концептуальні поняття, наприклад: держава - нейтральна, позаблокова; народ - наївний, негордий, упосліджений, стоїть на колінах; суспільство - важке, неспостережливе, не привчене питати; Україна - поневолена, змучена, вільна, незалежна, невизначена, хистка, компромісна, загартована.

Рідковживані негативно забарвлені лексеми недорікуватий, упосліджений, анахронічний надають високої експресивності авторському портретуванню української нації. В академічному тлумачному словнику української мови подано такі значення цих лексем: «НЕДОРі́КУВАТИЙ, a, е. 2. перен., розм. Неспроможний справитися з чим-небудь своїми силами; безпорадний» (Словник 5: 297); «УПОСЛІ́ДЖЕНИЙ (ВПОСЛІ́ДЖЕНИЙ), // У знач. прикм. Жалюгідний» (Словник 10: 467); «АНАХРОНІ́ЧНИЙ, а, е. Який $\epsilon$ анахронізмом (у 2 знач.), який не відповідає сучасності» (Словник 1: 44). Подібні негативні номінації зумовлені передусім бажанням авторки звернути читацьку увагу на проблеми розвитку нації та причини невдач українського народу.

Для мовностилістичного прийому іронії Ліна Костенко застосовує запозичену лексику, створює оказіоналізми, що репрезентують сучасність, європейськість нації: «У нас уже є маркети й супермаркети. Холдинги, лізинги й консалтинги. Рейтинги, брифінги, автобани й хабвеї. Жлобшоу, фбаст-фбуди і сендвич-бари. Рейдери, трейдери, рокери, брокери, кілери, ділери, трасти ...» (Костенко 120-121). 
Саме тематика міжчасся, розриву поколінь, зламу століть і образ головного героя, молодого інтелектуала, зумовили використання специфічної професійної лексики і термінології, наприклад: «Суспільство у нас важке. Конгломерат націй $i$ антинацій, звиклих до стагнацій $i$ профбанацій, дискримінацій і асиміляцій. Шлунок у такого суспільства безрозмірний, а спільного серця нема. А нема спільного серця - нема спільних цінностей (Костенко 231); «Наївний ми народ, українці. Мріємо про свободу в умовах глобалізації. <...> Та все дбаємо про злагоду в суспільстві, про консенсус $і$ компроміс» (Костенко 107). Як зазначає О. Ковацька: «Належність архіватора „Записок...” до колоніального радянського минулого маркована у дусі соцреалістичного кітчу, де homo sowietikus проходить ритуал соціалізації, обезличування, позначена втратою індивідуальності, підляганням особистості під шаблон: учень, студент, аспірант, кандидат, на додаток - майстер спорту» (293). Ці чинники й визначають комунікативну поведінку головного героя твору загалом. Його образ, який часто експлікований займенником я, головним чином моделює структуру автостереотипу, формує семантичне поле образу української нації, оскільки у творі нерідко актуалізоване відношення «я» до «нація», як частини до цілого: «І нація - це теж я. А якщо в цій нації є антинація, то прошу не плутати. Бо я належу до нації, яку обрав я і яка обрала мене - до красивої і шляхетної нації» (Костенко 161). Самохарактеристики головного героя найвиразніше формують авторський стереотип українця: «Фактично я теж неповноцінний громадянин, бо я терплю. По суті, $я$ давно вже по-справжньому не обурююсь, я знаю, що від мене нічого не залежить. За радянської влади людину хоч вважали гвинтиком тієї системи. А тепер повипадали і гвинтики, і шурупчики, i мотор забарахлив. Я ніхто. Я виборець. Я одиниця електорату. Я такий-то номер у списку. «Світ належить першим». Я стонадцятий» (Костенко 96).

Репрезентація національної ментальності в аналізованому романі відбувається також за допомогою займенника ми, що виступає контекстуальним синонімом до іменників народ, суспільство, українці, наприклад: "А такі, як оце ми, все надіються, що якось воно буде» (Костенко 96). Для характеристики нації займенник ми застосовано в контексті негативних характеристик: сепаратисти, націоналісти, самостійники, не такі, історично не обгрунтовані, бездомні, безпритульні. «Пізно ми заходилися будувати свою державу. Європа об'єднується, ми знов не такі. Сепаратисти, націоналісти, самостійники. Випадаємо з концепції «історично обгрунтованої інтеграції Європи». Ми взагалі якісь історично не обгрунтовані для Європи. А даремно. Наші бренди відповідають європейським трендам. Ми вже цілком глобалізувалися. Нашого цвіту по всіх борделях світу. Наші Синдбади плавають під чужими прапорами» (Костенко 120); «Ми бездомні у своєму домі, ми безпритульні у своїй країні» (Костенко 177). 
Етнонім українці як маркер національного стереотипу здебільшого використано в автокумунікації головного героя, проте саме форма діалогу дозволила застосувати символічний образ чайки для підсилення емоційності та увиразнення характеристики українців:

- Як ти думаєш, чому українці ніяк не можуть ідентибікувати себе як націю, навіть уже у власній державі?

- А чайка, яку зварили в каші, може себе ідентифікувати з собою? Тільки з кашею, - сказала вона (Костенко 95).

Критичне ставлення до українців у романі виражене іноді за допомогою елементів інтертексту й прямого мовлення героя-антипода: «- $B$ Tpeтє тисячоліття українці в"їхали з тим самим возом проблем, каже він, - 3 набором дрімучих стереотипів, з комплексом меншовартості. Світ приймає нові виклики, вирішує нагальні проблеми, а вони все борсаються в тих самих, старих, нецікавих і неактуальних для світу» (Костенко 116).

Відомо, що етнічні стереотипи, утворюючи певну систему знань про світ, відображають певні відмінності між народами. На основі дихотомії «свій» - «чужий» відбувається узагальнене протиставлення своєї нації іншим. Як стверджує С. Сердюк, «Етнічний стереотип відображає не дві, а набагато більше етнічних реальностей. Число гетеростереотипів, що розрізняються у структурі етнічного стереотипу, залежить як від історії міжетнічних відносин, так і від особливостей безпосереднього етноконтактного середовища» (11). У романі «Записки українського самашедшого» фіксуємо різні етноніми, зокрема: чехи, поляки, росіяни. Авторка здійснює протиставлення, оцінку свого народу в порівнянні 3 тими національностями, котрі мають геополітичний та культурний вплив на українців: «Росіянам теж багато що допекло, але вони - імперія, вони все одно певні, що Росія приречена на велич. А ми приречені на Росію. Ми завжди на когось або на щось приречені. Від того й колплекс меншовартості» (Костенко 118); «А чехи таки перемогли. Той небажаний їм гендиректор подав у відставку. Це ж не те, що ми, - кого не нав'яжуть, терпимо. Цілковита громадянська анемія. Навіть колінного рефллексу нема» (Костенко 61); Українці з поляками - це гримуча суміш» (Костенко 111). Факультативно в контекст твору введено також етнонім японці та топонім Грузія, які увиразнюють моделювання сучасного автостереотипу: «Це вже якщо у японця крівля поїхала, така мудра нація, то що ж тоді нам?» (Костенко 99); «Але Україна - не Грузія. Там лінію оборони тримають живі» (Костенко 331).

Мовностилістичні прийоми та художні образи, що застосовує Ліна Костенко для оцінки українського народу, відзначаються інтелектуальністю, створюють високу естетичність твору та здійснюють ефект позачасовості, розширюють межі осягнення у просторі та часі. Одну з переконливих ілюстрацій цих ознак спостерігаємо в алегоричному образі птаха, за допомогою якого авторка портретизує український народ: «Іноді мені украӥнці здаються таким великим гарним птахом, який сидить собі і не 
знає, що робиться на сусідньому дереві, який любить собі поспати, сховавши голову під крило. Крило тепле, притульне, сни історичні, красиві. М'язи розслабились, душа угрілася, - прокинувся, а дерево під ним спилюють, гніздо впало, пташенята порозліталися хто куди, сидять на інших деревах i цвірінькають вже по-іншому» (Костенко 156). В іншому випадку для диференційних етнічних ознак використано конкретну назву - дятел: «Приснився дятел, що клюе націю в скроню. Дятел був як дятел, дзьобатенький і пістрявий, а нація якась аморфна, розпливчаста, i все підставляє скроню» (Костенко 191).

Висновки та перспективи дослідження. Отже, у романі Ліни Костенко «Записки українського самашедшого» національний стереотип змодельовано за допомогою концептуальних понять нація, народ, українці, держава, суспільство, що постають домінувальними у вербалізації національних характеристик. Виразником авторської моделі стереотипу постає образ головного героя як представника українського соціуму XXXXI століття, комунікативна поведінка якого демонструє оцінне ставлення до свого народу. Оцінні номінації, що конструюють у тексті роману модель національного стереотипу, здебільшого мають негативну конотацію та позначені високою експресивністю. Ліна Костенко використовує різноманітні мовностилістичні засоби, синтаксичні конструкції, створює яскраві художні образи для портретування української нації, для акцентування уваги на проблемах сучасних українців, а тому автостереотип постає не ідеалізованим, критично осмисленим, що зумовлено індивідуальним досвідом письменниці, соціальними та політичними чинниками.

Перспективи подальших досліджень національного стереотипу в лінгвістиці полягають у виробленні критеріїв добору фактичного матеріалу, текстів різноманітних функціональних стилів та жанрів, а також у порівняльному вивченні специфіки моделювання стереотипів, їх вербалізації та динаміки у творчості різних письменників.

\section{Список використаної літератури}

Бацевич, Флорій. Основи комунікативної лінгвістики. Київ, 2009.

Белова, Ольга. Этнокультурные стереотипы в славянской народной традиции. Москва, 2005.

Богдан, Світлана “„Україна... А знаєте, таки є щось в сьому слові”. Етнічні стереотипи Лесі Українки за її листами». Дивослово, №10, 2002, с. 19-24.

Богдан, Світлана. «Моделювання мовноповедінкових стереотипів „чужих” у романі Ліни Костенко „Берестечко”». Наукові записки Національного університету «Острозька академія». Серія: Філологічна, вип. 17, 2010, с. 101-11.

Годзь, Наталія. Культурні стереотипи в українській народній казці. Автореф. дис. ... канд. філолософ. наук : 09.00.04. Харків, 2004.

Кісь, Оксана. «Стереотип фемінності українців у фольклорних та етнографічних джерелах». Наукові записки Івано-Франківського краєзнавчого музею, вип. 5-6. 2001, c. 88-97. 
Ковацька, Оксана. «„Записки українського самашедшого” Л. Костенко у світлі постколоніальної рецепції». Сучасні літературознавчі студії. Літературний дискурс: транскультурні виміри, вип. 12, 2015, с. 288-302.

Костенко, Ліна. Записки українського самашедшого. Київ, 2011.

Ляшук, Наталія. «Стереотип національного характеру українців у прозових жанрах фольклору». Лінгвостилістичні студї̈, вип. 4, 2016, с. 123-31.

Маслова, Валентина. Когнитивная лингвистика. Минск, 2004.

Попович, Людмила. «Стереотип мови в українській мовній картині світу». Українознавство, № 1-2, 2004, с. 318-23.

Сердюк, Світлана. «Функції етнічних стереотипів та їхня роль у формуванні етнічної ідентичності». Наукові записки НаУКМА. Теорія та історія культури, т. 19, 2001, c. $10-4$.

Серебрянська, Ірина. «Концепт зірка як стереотип етнокультурного мислення в мові української прози другої половини XX ст.». Лінгвістичні дослідження, вип. 32, 2011. c. 101-5.

Словник української мови, за ред. І. К. Білодіда. В 11 т. Київ: Наукова думка, 1970-1980.

Трифонов, Роман, і Стратілат, Олена. «Мовні засоби вербалізації та деконструкції стереотипів у книзі Максима Кідрука «Мексиканські хроніки»». Вісник Харківського національного університету ім. В.Н.Каразіна. Серія «Філологія», № 1048, вип. 67, 2013, с. 102-7.

Фалафівка, Олеся. «Мовні маркери стереотипності в описах національних характерів (на матеріалі української газетної публіцистики)». Лінгвістичні студї̈, вип. 32, 2016, c. 88-92.

Bartmiński, Jerzy. «0 stereotypach i profilowaniu slów kilka». Stereotypy: walka z wiatrakami? red. Anna Bujnowska, Joanna Szadura. Lublin, 2011, s. 33-51.

\section{References}

Batsevych, Florii. Osnovy komunikatyvnoi linhvistyky. Kyiv, 2009.

Belova, Ol'ga. Jetnokul'turnye stereotipy v slavjanskoj narodnoj tradicii. Moskva, 2005.

Bohdan, Svitlana. “"Ukraina... A znaiete, taky ye shchos v somu slovi”. Etnichni stereotypy Lesi Ukrainky za yii lystamy". Divoslovo, no. 10, 2002, pp. 19-24.

Bohdan, Svitlana. "Modeliuvannia movnopovedinkovykh stereotypiv "chuzhykh" u romani Liny Kostenko "Berestechko"”. Scientific Notes of Ostroh Academy National University: Philology Series, iss. 17, 2010, pp. 101111.

Godz, Nataliya. The cultural stereotypes in the Ukrainian popular folk fairy tales. PhD Thesis Abstract. Kharkiv, 2004.

Kis, Oksana. "Stereotyp feminnosti ukraintsiv u folklornykh ta etnohrafichnykh dzherelakh". Naukovi zapysky Ivano-Frankivskoho kraieznavchoho muzeiu, iss. 5-6. 2001, pp. 8897.

Kovatska, Oksana. "Notes of the Ukrainian Madman" L. Kostenko in the light of postcolonial reception". Modern literary studies. Literary discourse: transcultural dimensions, iss. 12, 2015, pp. 288-302.

Kostenko, Lina. Zapysky ukrayins'koho samashedshoho. Kyiv, 2011.

Lyashuk, Natalia. "The Ukrainians' National Character Stereotype in the Prose Genres of Folclore". Linguostylistic Studies, iss. 4, 2016, pp. 123-131.

Maslova, Valentina. Kognitivnaja lingvistika. Minsk, 2004.

Popovich, Lyudmila. "Stereotyp movy v ukrainskii movnii kartyni svitu”. Ukrainian Studies, no. 1-2, 2004, pp. 318-23.

Serdyuk, Svetlana. "Functions of the Ethnical Stereotypes and Their Role in Formation of Ethnical Identity". NaUKMA Research Papers. History and theory of culture, iss. 19, 2001, pp.10-4. 
Serebryanska, Iryna. "Kontsept zirka yak stereotyp etnokulturnoho myslennia v movi ukrainskoi prozy druhoi polovyny XX st.”. Lingvistichni doslidzhennja, iss. 32, 2011. pp. 101-5.

Slovnyk ukrainskoi movy, edited by I. K. Bilodid. 11 vols. Kyiv: Naukova dumka, 1970-1980.

Trifonov, Roman, and Stratilat, Elena. "Linguistic Means of Verbalization and Deconstruction of Stereotypes in Maxim Kidruk's Book "Mexican Chronicles"”. The Journal of V. N. Karazin Kharkiv National University. Series "Philology", no. 1048, iss. 67, 2013, pp. 102-7.

Falafivka, Olesya. "Linguistic Markers of Stereotype in National Character Descriptions (Based on Ukrainian Newspaper Articles)". Linguistic Studies, iss. 32, 2016, pp. 88-92.

Bartmiński, Jerzy. “O stereotypach i profilowaniu slów kilka”. Stereotypy: walka z wiatrakami? red. Anna Bujnowska, Joanna Szadura. Lublin, 2011, s. 33-51.

Стаття надійшла до редколегії 21.09.2020 